\title{
Blæðingar frá meltingarvegi í íslensku og erlendu samhengi - yfirlitsgrein
}

\section{Jóhann P. Hreinsson ${ }^{1}$ læknir}

\section{Einar S. Björnsson ${ }^{2,3}$ læknir}

'Meltingarlækningum, lyflækningasviði Sahlgrenska sjúkrahússins í Gautaborg, Svípjóð, ææknadeild Háskóla Íslands, ${ }^{3}$ meltingarlækningum, lyflækningasviði Landspítala.

Fyrirspurnum svarar Jóhann P. Hreinsson, hreinssonjp@gmail.com

\section{Á G R I P}

Bráð blæðing frá meltingarvegi er algeng ástæða komu á bráðamóttöku og innlagnar á spítala. Pessum blæđingum er vanalega skipt í efri og neðri meltingarvegarblæðingar. Í pessari yfirlitsgrein verður farið yfir nýgengi pessara blæðinga, áhættupætti, orsakir, pátt blóðpynningarlyfja, mat á alvarleika blæđinga, meðferðarúrræð og horfur. Reynt verður að varpa ljósi á petta viðfangsefni i íslensku heilbrigðiskerfi en einnig í víðara samhengi.

\section{Inngangur}

Blæðingar frá meltingarvegi eru algeng orsök innlagnar á spítala, nýgengi blæðinga frá efri hluta meltingarvegar var á árinu 2010 í framskyggnri rannsókn á Íslandi 87/100.000 íbúa ${ }^{1}$ og nýgengið var hið sama hvað varðar blæðingu frá neðri hluta meltingarvegar. ${ }^{2}$ Erlendis hefur nýgengi blæðinga frá efri hluta meltingarvegar ver¡ð talið um 90-110/100.000 íbúa/ár í nýlegum framskyggnum rannsóknum, ${ }^{3-5}$ en minna í peim fáu og eldri rannsóknum sem kannað hafa nýgengi blæðinga frá neðri hluta meltingarvegar, eða 2143/100.000 íbúa/ár. ${ }^{6-8}$ Nýgengi pessara blæðinga eykst mikið með aldri. ${ }^{1,2}$ Pannig má búast við að með vaxandi aldri pýðis í hinum

Tafla I. Orsakir blæđinga frá efri hluta meltingarvegar.

\begin{tabular}{|c|c|c|c|c|}
\hline & $\begin{array}{l}\text { Hreinsson } \\
\text { et al. } 2013^{1} \\
n=156(\%)\end{array}$ & $\begin{array}{l}\text { Theocharis } \\
\text { et al. } 2008^{5} \\
n=353(\%)\end{array}$ & $\begin{array}{l}\text { Loperfido } \\
\text { et al. } 2009^{3} \\
n=539(\%)\end{array}$ & Spönn \% \\
\hline $\begin{array}{l}\text { Maga- og } \\
\text { skeifugarnarsár }\end{array}$ & $62(40)$ & $235(67)$ & $286(53)$ & $40-67$ \\
\hline Magasár & $23(15)$ & $113(32)$ & $91(17)$ & $15-32$ \\
\hline Skeifugarnarsár & $32(21)$ & $116(33)$ & $179(33)$ & $21-33$ \\
\hline $\begin{array}{l}\text { Maga- og } \\
\text { skeifugarnarsár }\end{array}$ & $7(4)$ & $6(2)$ & $16(3)$ & $2-4$ \\
\hline Vélindabólga & $15(10)$ & --- & $23(4)$ & $4-10$ \\
\hline $\begin{array}{l}\text { Mallory-Weiss- } \\
\text { heilkenni }\end{array}$ & $20(12)$ & $15(4)$ & $16(3)$ & $3-12$ \\
\hline $\begin{array}{l}\text { Fleiður/bólga í } \\
\text { maga/skeifugörn }\end{array}$ & $7(5)$ & $30(8)$ & $56(10)$ & $5-10$ \\
\hline Magakrabbamein & $5(3)$ & $28(8)$ & $28(5)$ & $3-8$ \\
\hline Æðamissmíði & 8 (5) & --- & $15(3)$ & $3-5$ \\
\hline Æモðagúlar í vélinda & $6(4)$ & $22(6)$ & $62(12)$ & $4-12$ \\
\hline Engin orsök fannst & $10(6)$ & $12(3)$ & $27(5)$ & $3-6$ \\
\hline Annad & $23(15)$ & $14(4)$ & $27(5)$ & $4-15$ \\
\hline
\end{tabular}

vestræna heimi muni blæðingar frá meltingarvegi verða enn fyrirferðarmeiri á komandi áratugum. ${ }^{9}$

Bráð blæðing frá meltingarvegi er vanalega skilgreind sem sýnileg blæðing sem leiðir til innlagnar á spítala eða á sér stað hjá inniliggjandi sjúklingi. ${ }^{8,10-12}$ Blæðingum er skipt í efri og neðri blæðingar eftir pví hvoru megin við trefjavefsband Treitz (ligament of Treitz) blæðir en pað er staðsett á mótum skeifugarnar (duodenum) og ásgarnar (jejunum)., ${ }^{7,10,13}$ Lagt hefur verið til að skilgreina blæðingar í ás- og dausgörn (ileum) sem blæðingar frá miðju meltingarvegar par sem pær blæðingar eru talsvert frábrugðnar blæðingum frá ristli, en sú skilgreining hefur ekki náð fótfestu enn sem komið er. ${ }^{14,15}$

\section{Orsakir}

Maga- og skeifugarnarsár eru algengustu orsakir blæðinga frá efri hluta meltingarvegar, eða um 40-60\% í flestum rannsóknum (tafla I). Aðrar algengar orsakir eru vélindabólga og slímhúðarrof á mótum vélinda og maga, einnig pekkt sem Mallory-Weissheilkenni (tafla I). Tíðni maga- og skeifugarnarsára hefur pó farið minnkandi síðastliðna áratugi, líklega vegna meiri vitundar um áhættupættina bólgueyðandi lyf sem ekki eru sterar (non-steroidal anti-inflammatory drugs) og $\mathrm{H}$. pylori en algengi bakteríunnar hefur einnig lækkað verulega. Tilkoma prótonupumpu-hemla hefur einnig spilað rullu. ${ }^{3,7,16}$

Algengasta orsök bráðra blæðinga frá neðri hluta meltingarvegar er blæðing frá ristilpokum en aðrar algengar orsakir eru blóðpurrðarbólga í ristli og aðrir bólgusjúkdómar í ristli (tafla II). Tíðni blóðpurrðar virðist hafa farið vaxandi síðastliðna áratugi ef hlutfall pessara blæðinga af öllum blæðingum frá neðri hluta meltingarvegar er borið saman á milli eldri og nýrri rannsókna 
Tafla II. Orsakir blæđinga frá neđri hluta meltingarvegar, fjöldi (\%).

\begin{tabular}{|c|c|c|c|c|c|}
\hline & $\begin{array}{l}\text { Hreinsson et al. } \\
2016^{18} n=325\end{array}$ & $\begin{array}{l}\text { Longstreth et al. } \\
1997^{8} n=219\end{array}$ & $\begin{array}{c}\text { Gayer et al. } \\
2009^{19} n=608\end{array}$ & $\begin{array}{c}\text { Arroja et al. } \\
2011^{10} n=364\end{array}$ & Spönn \% \\
\hline Ristilpokar & $73(22)$ & $91(42)$ & $227(37)$ & $77(21)$ & $21-42$ \\
\hline Blóðpurrðarbólga í ristli & $44(14)$ & $19(9)$ & $65(11)$ & $88(24)$ & $9-24$ \\
\hline Ristilkrabbamein & $23(7)$ & $20(9)$ & $72(12)$ & $46(12)$ & $7-12$ \\
\hline Bólgusjúkdómur & $38(12)$ & $16(7)$ & $33(5)$ & $11(3)$ & $3-12$ \\
\hline Gyllinæð & $39(12)$ & $10(5)$ & $128(21)$ & $14(4)$ & $4-21$ \\
\hline Eftir sepatöku & $3(1)$ & $9(4)$ & - & $14(4)$ & $1-4$ \\
\hline Engin orsök fannst & $31(10)$ & $26(12)$ & $21(4)$ & $30(8)$ & $3-12$ \\
\hline ÆEðamissmíðar & $12(4)$ & $6(3)$ & $14(2)$ & $18(5)$ & $2-5$ \\
\hline Góðkynja separ í ristli & $10(3)$ & - & - & $18(5)$ & $3-5$ \\
\hline Annað & $52(15)$ & $22(9)$ & $48(8)$ & $48(14)$ & $8-15$ \\
\hline
\end{tabular}

(tafla II) en tíðni blæðinga frá ristilpokablæðingum hefur staðið í stað á Íslandi undanfarin 10 ár ${ }^{17}$

\section{Áhættupættir}

Lyf

Рað er vel pekkt að bólgueyðandi lyf geti orsakað maga- og/eða skeifugarnarsár. ${ }^{20-24}$ Petta kemur til vegna staðbundinna áhrifa pessara lyfja í slímhúð ${ }^{24}$ auk hamlandi áhrifa peirra á ensímið COX-1 sem er meðal annars mikilvægt til pess að viðhalda heilbrigðri magaslímhúð. ${ }^{25}$ Pessi lyf geta jafnframt valdið skaða neðar í meltingarvegi, bæði í smágirni og ristli. ${ }^{26-30}$ Hemlun ensímsins COX-2 er pað sem veldur bólgueyðandi, verkjastillandi og hitalækkandi áhrifum pessara lyfja, ${ }^{25}$ pví voru sértækir COX-2 hemlar próaðir til pess að sneiða hjá aukaverkunum tengdum hemlun á COX-1. Hætta á sárasjúkdómi í meltingarvegi af völdum sértækra COX-2 hemla er pó enn til staðar en er mun minni en fyrir bólgueyðandi lyf sem ekki eru sterar. ${ }^{31}$ Vert er að hafa í huga að samhliðanotkun asetýlsalicýlsýru, til dæmis hjartamagnýls, með COX2 hemlum virðist draga verulega úr pessum ávinningi. ${ }^{31,32}$

\section{Hjartamagnýl}

Hjartamagnýl heyrir undir bólgueyðandi lyf sem ekki eru sterar en er pó oft flokkað utan peirra vegna óafturkræfrar blóðflöguhamlandi verkunar. ${ }^{33}$ Jafnvel pótt lyfið sé gefið í smáum skömmtum hefur hjartamagnýl einnig verið tengt sáramyndunum bæði í efri ${ }^{34-36}$ og neðri hluta meltingarvegar. ${ }^{26-28,37,38}$ Nota má vefsíðuna asarisk.doctime.es/calculator/en til pess að auðvelda ákvarðanatöku um pað hvaða sjúklingar á hjartamagnýli eiga að fá prótonpumpuhemla í forvarnaskyni fyrir blæðingu.

\section{Blóðpynningarlyf}

Blóðpynningarlyf auka líkur á blæðingu frá meltingarvegi ${ }^{34,39,40}$ en nokkur atriði parf að hafa í huga með tilliti til sambands notkunar slíkra lyfja og blæðinga frá meltingarvegi. Gamalreynda lyfið warfarín (kóvar) hefur pann kost að pynningarstyrkleikinn er vel mælanlegur með INR, pað er ódýrt, auk pess að hægt er að snúa við blóðpynningu á skömmum tíma með K-vítamíni og plasma. Auk pess er hægt að snúa pynningu við mjög snögglega með próthrombín komplex sem er pó talsvert dýrari meðferð. ${ }^{41}$ Vert er að hafa í huga að nauðsynlegt er að gefa K-vítamín til pess að viðhalda viðsnúningsáhrifum plasma eða próthrombín-komplex eftir að áhrif peirra fara pverrandi. ${ }^{41}$ Ókostir kóvar-meðferðar eru meðal annars lyfjamilliverkanir og tíðar mælingar en pað er spurning hvort pétt eftirlit kóvar-meðferðar skili sér í betri meðferðarheldni. Af nýrri blóðpynningarlyfjunum (direct oral anticoagulants, DOACs), apixaban (Eliquis $\left.{ }^{\circledR}\right)$, rivaroxaban (Xarelto ${ }^{\circledR}$ ), dabigatran (Pradaxa ${ }^{\circledR}$ ) og edoxaban (Lixiana ${ }^{\circledR}$ ), virðast apixaban og edoxaban ekki auka líkur á blæðingu frá meltingarvegi í samanburði við kóvar en hættan virðist vægt aukin fyrir rivaroxaban og dabigatran. ${ }^{42}$ Kostir nýju blóðpynningarlyfjanna eru minni milliverkanir og sjúklingar eru lausir við reglulegar blóðmælingar sem fylgja kóvar. Pó parf að hafa í huga að meiri reynsla er fyrir kóvar með tilliti til auka- og milliverkana og færð hafa verið rök fyrir pví að mæla eigi virkni nýju blóðpynningarlyfjana reglulega, að minnsta kosti í völdum sjúklingahópum en tækni til slíkra mælinga er enn skammt á veg komin. ${ }^{43}$ Hægt er að snúa við virkni dabigatran með idarucizumab (Praxbind ${ }^{\circledR}$ ) og virkni apixaban og rivaroxaban með nýlega sampykkta lyfinu andexanet alfa (Andexxa ${ }^{\circledR}$ ), en kostnaður pessara lyfja er talsverður. ${ }^{44}$ Færa má rök fyrir pví að mikilvægast í pessari umræðu sé hvaða lyf minnki mest áhættuna á blóðpurrðarslagi í heila eða heilablæðingu. Nýleg safngreining (meta-analysis) sem tók til sjúklinga með gáttatif, skoðaði apixaban sérstaklega í samanburði við kóvar og önnur nýrri blóðpynningarlyf. ${ }^{45}$ Safngreiningin tók bæði til slembiraðaðra íhlutunarrannsókna (randomized controlled trials) par sem meirihluti gagna er frá lyfjafyrirtækjum, og gagna úr raunverulegum aðstæðum. Niðurstöðurnar bentu til pess að apixaban sé að minnsta kosti jafn gott og önnur lyf til pess að draga úr líkum á blóðpurrðarslagi, auk pess að koma best út með tilliti til hættulegra aukaverkan, svo sem heilablæðinga eða alvarlegra blæðinga frá meltingarvegi. ${ }^{45}$

\section{Helicobacter pylori}

Tilvist og skaðleg áhrif H. pylori á maga og skeifugörn hafa verið pekkt frá pví snemma á níunda áratuginum. ${ }^{46}$ Talið er að H. pylori 
smitist helst í gegnum saur/munn smit en einnig munn/munn smit. ${ }^{47}$ Með auknu hreinlæti og betri vistarverum seinustu áratugi virðist hafa dregið verulega úr algengi $H$. pylori á Íslandi. ${ }^{4}$ Greining fer vanalega fram með töku og greiningu vefjasýna úr magaspeglun. Einnig má greina H. pylori með svokölluðu ureasablástursprófi sem er mjög næmt og sértækt próf, pað er bó aðallega notað til að kanna árangur af upprætingarmeðferð. ${ }^{47}$

\section{Mat}

Við mat á sjúklingum með bráða blæðingu frá meltingarvegi skiptir sögutaka miklu máli, í mörgum tilvikum getur birtingarmynd blæðingarinnar og lyfjasaga gefið góðar vísbendingar um orsök blæðingar. Sjúklingar sem hafa blóðug eða korglituð uppköst eru með blæðingu frá efri hluta meltingarvegar. Peir einstaklingar sem hafa tjöruhægðir (melena) eru líklegri til pess að hafa blæðingu frá efri hluta meltingarvegar en um 5\% peirra hafa blæðingu frá neðri hluta meltingarvegar..$^{18}$ Blæðing frá neðri hluta meltingarvegar lýsir sér vanalega með ferskri blæðingu (hematochezia) eða dumbrauðum (maroon-colored) hægðum. Ef sjúklingur hefur talsverða ferska blæðingu og óstöðug lífsmörk er mikilvægt að hafa í huga að $2 \%$ allra sjúklinga með blæðingu frá efri hluta meltingarvega hafa ferska blæðingu um endaparm ${ }^{1}$ og pví mikilvægt að gera magaspeglun sem fyrst í pessum sjúklingahópi. Magaspeglun ætti að fara fram innan 24 klukkustunda eftir komu á spítala en ekki hefur verið sýnt fram á hag við notkun styttri viðmiða (svo sem 12 klst.) en erlendar leiðbeiningar hafa pó fyrirvara á pví að mjög óstöðugir sjúklingar kunni að hafa hag af pví að vera magspeglaðir sem fyrst, en pó ekki fyrr en tapað vökvarúmmál hefur verið bætt upp og lífsmörk stöðug. ${ }^{49}$ Ristilspeglun ætti að gera innan sólarhrings í sjúklingum með slæm klínísk teikn eða merki um viðvarandi blæðingu, hjá öðrum ætti að framkvæma rannsókn við næsta hentugleika. ${ }^{50}$

Hafa má í huga eftirfarandi hluti sem skipta máli í sögu: uppköst, í upphafi óblóðug sem síðar verða blóðug, tengjast MalloryWeiss-heilkenni, bólgueyðandi lyf sem ekki eru sterar benda til sára í meltingarvegi, lifrarsjúkdómur eða líkamleg teikn um lifrarsjúkdóm geta bent til blæðingar frá æðagúlum í vélinda, fersk og verkjalaus blæðing um endaparm samrýmist ristilpokablæðingu, skyndilegur kviðverkur með niðurgangi og blóði um endaparm getur bent til blóðpurrðar í ristli, tíðar klósettferðir með slími og blóði benda til ristil- eða parmabólgusjúkdóma (inflammatory bowel disease) og að lokum benda hægðatregða og verkir í endaparmi til gyllinæðar eða rifu í endaparmi. Pó ber pess að geta að skyndilegur niðurgangur sem hefur hafist innan eins til tveggja sólarhringa hjá sjúklingi sem leitar læknishjálpar (stundum blóðugur niðurgangur) er oftast vegna bráðrar iðrasýkingar af bakteríuvöldum. Slíka sjúklinga á yfirleitt ekki að spegla nema fyrir liggi neikvæðar saurræktanir hjá sjúklingi sem sýnir engin batamerki. Fyrri saga um blæðingu frá meltingarvegi og áfengisneysla eru einnig veigamiklir pættir í sögu.

Nýlega hafa verið sett fram áhættulíkön sem spá fyrir um hvaða einstaklingar með bráða blæðingu frá efri hluta meltingarvegar sem koma á bráðamóttöku munu ekki purfa meðhöndlun á spítala og er pannig hægt að útskrifa heim með áætlun um uppvinnslu síðar. Glasgow-Blatchford blæðingarlíkanið (mdcalc.com/glasgow-
Tafla III. Sjúklingar með eitt stig eða minna hafa 96\% líkur á pví að purfa ekki meðhöndlun á spítala.

\begin{tabular}{lc}
\hline $\mathrm{SHA}_{2} \mathrm{PE}$-áhættulíkanið & Stig \\
\hline Slagbilsprýstingur <100mmHg (Systolic pressure) & 1 \\
\hline Blóðrauðagildi (Hemoglobin value $(\mathrm{g} / \mathrm{L}))$ & 2 \\
\hline$<105$ & 1 \\
\hline $105-120$ & 1 \\
\hline Blóðflöguhamlandi meðferð (Antiplatelet therapy) & 1 \\
\hline Blóðpynningarmeðferð (Anticoagulant therapy) & 1 \\
\hline Púls >100 slög á mínútu (Pulse) & 1 \\
\hline Blæðing á bráðamóttöku (Emergency room bleeding) & \\
\hline
\end{tabular}

blatchford-bleeding-score-gbs) hefur komið best út af peim líkönum sem snúa að blæðingum frá efri hluta meltingarvegar, en pað inniheldur efirfarandi breytur: Blóðrauði, úrea, slagbilsprýstingur, kyn, púls $\geq 100$, tjöruhægðir, yfirlið, saga um lifrarsjúkdóm og hjartabilun. ${ }^{51}$ Sjúklingar með 1 stig eða minna á áhættulíkaninu hafa tæplega 99\% líkur á pví að purfa ekki meðhöndlun á spítala. ${ }^{51}$

Áhættulíkön með tilliti til blæðinga frá neðri hluta meltingarvegar eru skemur á veg komin en eitt slíkt hefur verið próað hér á Íslandi, SHA PE líkanið (tafla III), en pað hefur ekki verið sannreynt á framskyggnum hátt hér á landi eða í erlendu pýði. ${ }^{52}$ Aðeins 4 af 181 (2\%) sjúklingum sem notaðir voru til pess að gagnreyna líkanið voru ranglega flokkaðir sem sjúklingar ólíklegir til pess að purfa meðhöndlun á spítala. Sjúklingar með eitt stig eða minna samkvæmt $\mathrm{SHA}_{2}$ PE-líkaninu hafa 96\% líkur á pví að purfa ekki meðhöndlun á spítala. Oakland-líkanið, (mdcalc.com/oaklandscore-safe-discharge-lower-gi-bleed) er annað slíkt áhættulíkan sem var próað út frá rannsókn sem var úttekt á landsvísu í Bretlandi sem náði til tæplega 2400 sjúklinga með blæðingu frá neðri hluta meltingarvegar, pau sannreyndu líkanið á tveimur breskum spítölum sem ekki tóku pátt í rannsókninni. ${ }^{53}$ Líkanið inniheldur breyturnar: aldur, kyn, fyrri saga um blæðingu frá neðri hluta meltingarvegar, niðurstöður endaparmsskoðunar, hjartsláttur, slagbilsprýstingur og blóðrauðagildi. Sjúklingar með 8 stig eða minna höfðu 95\% líkur á pví að purfa ekki meðhöndlun á spítala. ${ }^{53}$

\section{Meðferð}

\section{Lyf}

Prótonupumpu-hemlar eru notaðir við blæðingum frá efri hluta meltingarvegar en slembiraðaðar rannsóknir hafa sýnt fram á lægri tíðni endurblæðinga, minni hættu á endurtekinni magaspeglun og sömuleiðis minni hættu á skurðaðgerð. ${ }^{54,55}$ Óvissu hefur gætt um hvort dreypi með prótonupumpu-hemli hafi ávinning fram yfir töflumeðferð eða ósamfellda meðferð í æð en dreypi er dýrara, eykur hjúkrunarpyngd og er hamlandi fyrir sjúkling. Alpjóðlegar leiðbeiningar frá 2010 taka ekki skýra afstöðu til pessarar spurningar ${ }^{56}$ og nýrri leiðbeiningar frá Evrópu og Asíu gera pað ekki heldur en ýja pó að pví að sídreypi geti verið óparfi. ${ }^{49,57}$ Nýlegar safngreiningar benda sterklega til pess að meðferð með dreypi borið saman við meðferð með töflum/ósamfelldri meðferð í æð minnki ekki líkur á klínískt mikilvægum endapunktum, svo 


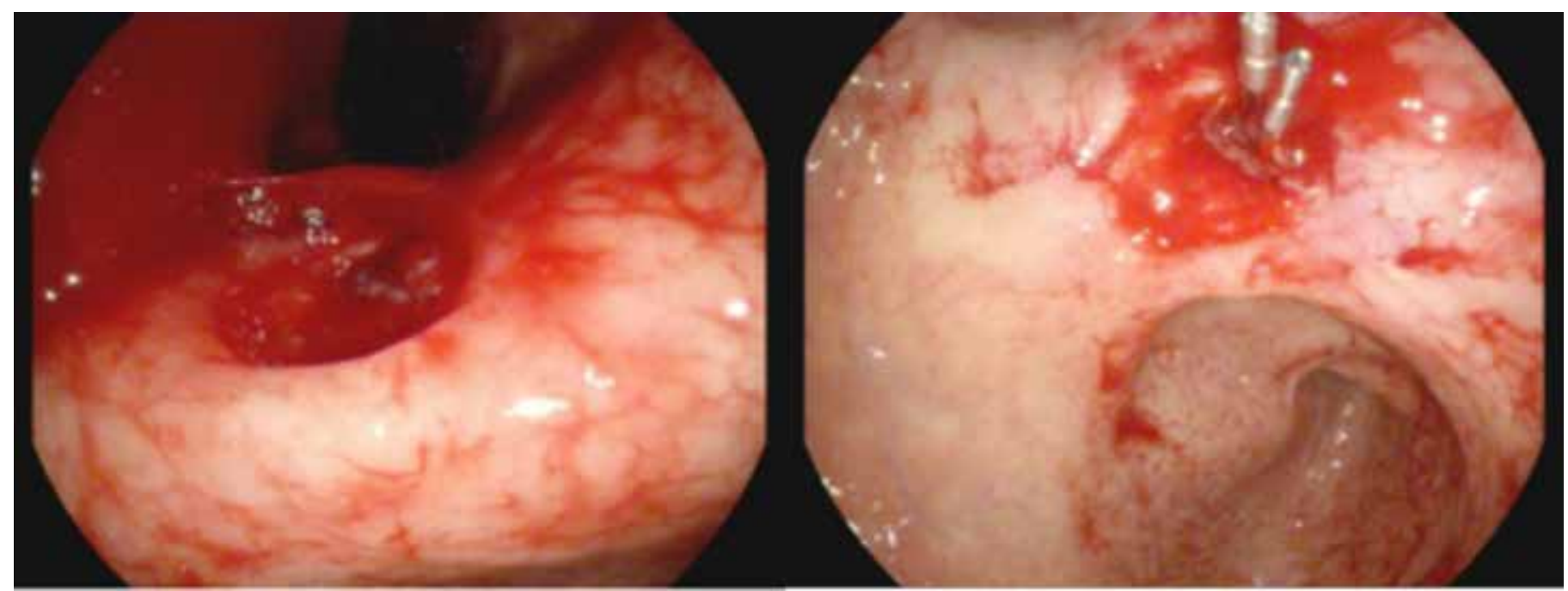

Mynd 1. Á vinstri hluta myndar má sjá blæðandi magasár. Á hægri hluta myndar má sjá hvar blæðing hefur verið stöðvuð með heftingu (hemoclips).

sem endurblæðingu, lengri spítaladvöl, skurðaðgerð eða dauða. ${ }^{56,58}$ Önnur pessara safngreininga sýndi ekki fram á ávinning af meðferð í æð borið saman við um munn ${ }^{58}$ en hin $^{56}$ gerði ekki greinarmun á milli meðferðar um munn og ósamfelldrar meðferðar í æð par sem heildarsýrumhemjandi áhrif pessara meðferðarleiða er svipuð pó að meðferð í æð virki fyrr. ${ }^{59}$ Ef meðhöndla ætti án dreypis gæti verið skynsamlegt að gefa 80 mg esomeprasól í æð sem hleðsluskammt og 40 mg x 2 í æð eftir pað.

Allir sjúklingar sem taldir eru vera með blæðingu frá æðagúlum í vélinda ætti að meðhöndla sem fyrst með terlipressin (Glypressin ${ }^{\circledR}$ ) 2 mg x 6 í æð, sem er smíðuð hliðstæða vasopressin en pað dregur saman garnahengisslagæðar (mesenteric arteries) og minnkar portæðaflæði. ${ }^{60}$ Af æðavirkum lyfjum í iðrablóðrás (terlipressin, vasopressin, somatostatin og smíðuð hliðstæða pess octreotide), er terlipressin eitt og sér eina lyfið sem sýnt hefur verið fram á að dragi úr hættu á dauða hjá sjúklingum með blæðingu frá æðagúlum í vélinda, hlutfallsleg áhætta 0,66, 95\% ÖB 0,49-0,88. ${ }^{61}$ Jafnframt hefur verið sýnt fram á pað að vikulöng sýklalyfjameðferð (svo sem ceftriaxone $1 \mathrm{~g} \times 1$ ) í pessum sjúklingahópi dregur úr sýkingum (HÁ 0,43 95\% ÖB 0,19-0,97), endurblæðingu (HÁ 0,53 95\% ÖB 0,38-0,74) og dauða (HÁ 0,79 95\% ÖB 0,63-0,98). ${ }^{62}$ Ekki hefur verið sýnt fram á ávinning af meðferð með prótonupumpuhemlum í blæðingum frá æðagúlum í vélinda. ${ }^{60}$

Sýklalyfið erythromycín er notað fyrir sjúklinga með alvarlega blæðingu frá efri hluta meltingarvegar. Erythromycín er motilín viðtakaörvi (agonist) í maga sem eykur magahreyfingar og flýtir pannig fyrir tæmingu maga en ef mikið blóð er í maga torveldar pað greiningu blæðingarstaðar og meðhöndlun. ${ }^{57}$ Mælt er með að gefa stakan 250 mg skammt í æð 30-120 mínútum fyrir speglun, en sýnt hefur verið fram að pað auki yfirsýn, minnki pörf á endurtekinni magaspeglun, dragi úr blóðgjöfum og stytti spítaladvöl. ${ }^{57}$

\section{Blóðgjöf}

Samkvæmt ráðleggingum blóðbanka Landspítala frá 2012 er ráðlagt að halda blóðrauða yfir 100g/L í blæðandi sjúklingum. ${ }^{63}$ Erlendis er víða farið аð miða við 70-90g/L, en $>90 \mathrm{~g} / \mathrm{L}$ í einstaklingum með stórfellda blæðingu, krans-, útlægan eða heilaæðasjúkdóm. ${ }^{49,50,57}$ petta viðmið byggist aðallega á tveimur slembiröðuðum rannsóknum sem náðu einvörðungu til einstaklinga með blæðingu frá efri hluta meltingarvegar, ${ }^{64,65}$ útilokaðir voru einstaklingar með stórfellda blæðingu (skilgreint sem neyðarblóð gefið, merki um lost eða speglun á bráðamóttöku/gjörgæslu, ${ }^{64}$ ekki skilgreint ${ }^{65}$ ) og krans-, útlægan eða heilaæðasjúkdóm. ${ }^{65}$ Niðurstöður sýndu fram betri 6 vikna lifun (95\% á móti 91\% HÁ 0,55 95\% ÖB 0,33-0,92) og minni hættu á áframhaldandi blæðingu (10\% á móti 16\%, HÁ 0,68 95\% ÖB 0,47-0,98) hjá sjúklingum með blóðgjafapröskuld $<70 \mathrm{~g} / \mathrm{L}$ borið saman við pá með pröskuld $<90 \mathrm{~g} / \mathrm{L} .{ }^{65}$ Sjúklingar sem fengu blóð ef blóðrauði féll undir 80g/L höfðu ekki verri 28 daga horfur borið saman við pá sem fengu blóðgjöf við blóðrauða <100g/L. ${ }^{64}$

\section{Íhlutanir}

Blæðingu frá meltingarvegi má stundum meðhöndla beint, í flestum tilfellum er pað gert með speglunartækni en í einstaka tilfelli er pörf á stíflun slagæða með æðapræðingu eða skurðaðgerð. Leiðir til pess að meðhöndla blæðingu með speglunartæki eru nokkrar en pað má skipta peim gróflega í sprautumeðferð (oftast adrenalín), brennslu (argon plasma, rafmagn eða hiti) og meðhöndlun með par til gerðum búnaði speglunartækis, svo sem heftingu sem virkar eins og heftibyssa, eða teygjumeðferð sem er beitt á æðagúla í vélinda. Á mynd 1 má sjá dæmi um virka blæðingu frá magasári og hvernig pað er meðhöndlað með speglunartæki. Seinast má nefna TIPS (transjugular intrahepatic portosystemic shunt) sem neyðarmeðferð við blæðingu frá æðagúlum í vélinda ef lyfjaeða speglunartækismeðferð duga ekki til en slík aðgerð dregur úr prýstingi í portæðakerfi með pví að leiða hluta bláæðablóðrásar fram hjá lifur. ${ }^{60}$ 
Um 24\% peirra sem eru með blæðingu frá efri hluta meltingarvegar á Íslandi eru meðhöndluð með speglunartæki ${ }^{1}$ en $7 \%$ peirra sem eru með blæðingu frá neðri hluta meltingavegar. ${ }^{2}$ Innan við $2 \%$ allra pessara sjúklinga eru meðhöndluð með stíflun á slagæð eða skurðaðgerð., ${ }^{1,2}$

\section{Framhald og horfur}

Blóðflöguhamlandi og blóðpynningarlyf

Algeng spurning sem vaknar við meðhöndlun sjúklinga með bráða blæðingu frá meltingarvegi er hvort og hvenær skuli stöðva og endurvekja blóðflöguhamlandi eða blóðpynningarlyf. Blóðflöguhamlandi lyfið hjartamagnýl ætti að endurvekja sem fyrst hjá sjúklingum með blæðingu frá meltingarvegi. Petta er byggt á slembiraðaðri rannsókn sem náði einvörðungu til einstaklinga með sár í efri hluta meltingarvegar (peptic ulcer), en hún sýndi fram á lægri tíðni dauða sem tengdist hjartakvillum, heilaslögum og meltingarvegakvillum í peim sem fengu hjartamagnýl strax eftir speglun (1\%) borið saman við pá sem fengu hjartamagnýl 8 vikum síðar (10\%). ${ }^{66}$ Evrópskar og asískar leiðbeiningar í efri blæðingum ráðleggja að hjartamagnýl sé endurvakið strax nema speglun sýni fram á blæðandi sár eða sár með sýnilegri æð, pá innan priggja daga. ${ }^{49,57}$ Í neðri blæðingum ráðleggja breskar og amerískar leiðbeiningar að stöðva ekki hjartamagnýl. ${ }^{50,67}$ Séu einstaklingar án sögu um hjarta- eða æðasjúkdóma á hjartamagnýli til forvarnar, mæla erlendar leiðbeiningar með pví að meðferð sé hætt og ekki endurvakin nema skýr ástæða pyki til. ${ }^{49,50,57,67}$

Fyrir sjúklinga á tvöfaldri blóðflöguhamlandi meðferð er mælt með pví að halda áfram meðferð ef peir hafa blæðingu frá efri hluta meltingarvegar nema ef speglun sýnir fram á blæðandi sár eða sár með sýnilegri æð, en pá er mælt með að halda áfram með hjartamagnýl en stöðva hitt blóðflöguhamlandi lyfið, fá í kjölfarið álit hjartalæknis og endurvekja fulla blóðflöguhamlandi meðferð sem fyrst. ${ }^{57}$ Hjá sjúklingum með blæðingu frá neðri hluta meltingarvegar er mælt með pví að halda áfram með tvöfalda blóðflöguhamlandi meðferð ef saga er um nýlegt kransæðaheilkenni eða stoðnet. ${ }^{50,67}$ Ef ákveðið er að stöðva annað lyfið skal halda hjartamagnýl áfram en endurvekja fulla meðferð innan 5-7 daga. ${ }^{50,67}$ Vísindagögnin á bak við pessar leiðbeiningar eru mjög takmörkuð og byggja aðallega á pví að sýnt hefur verið fram á að dánartíðni einstaklinga sem hætta á blóðflöguhamlandi meðferð og eru með nýlegt stoðnet í kransæð eða kransæðaheilkenni er talsvert aukin. ${ }^{49,50,57,67}$

Blóðpynningarmeðferð skal stöðva hjá einstaklingum með bráða blæðingu frá meltingarvegi, í alvarlegri blæðingum er rétt að snúa blóðpynningu við í samráði við meltingarlækni. Mælt er með pví að endurvekja hana sem fyrst, en rannsóknir sem styðja við pessar ráðleggingar eru mjög takmarkaðar. 49,50,57,67

\section{Horfur}

Um 6-17\% sjúklinga með blæðingu frá efri hluta meltingarvegar og 26\% sjúklinga með blæðingu frá neðri hluta meltingarvegar blæða aftur í sömu legu. ${ }^{3,5,16,68}$ Á Íslandi blæða 13\% (95\% ÖB 9-17\%) peirra með efri blæðingu [óbirt gögn] og 20\% (95\% ÖB 15-24\%) peirra með neðri blæðingu ${ }^{69}$ á næstu 5 árum eftir útskrift, sem er um 6 sinnum (95\% ÖB 2,4-15) [óbirt gögn] og 6,9 sinnum meira (95\% ÖB 3,4-14) ${ }^{69}$ en viðmiðunarhópur pegar leiðrétt er fyrir kyni, aldri og fylgisjúkdómum. Skurðaðgerðir og dauðsföll af völdum blæðinga frá meltingarvegi eru mjög sjaldgæf. Á Íslandi 2010 fóru 2\% (3/156) og $0 \%(0 / 163)$ í skurðaðgerð vegna blæðinga frá efri og neðri hluta meltingarvegar en 1,2\% og 1,3\% dóu vegna blæðingarinnar en peir sjúklingar voru fjölveikir., Enginn purfti á stíflun á slagæð að halda á árinu 2010 pegar framskyggn rannsókn á blæðingum fór fram á Landspítala en pó er einstaka sinnum pörf á pessu inngripi pegar speglunarmeðferð dugir ekki og/eða skurðaðgerð er ekki æskileg vegna ástands sjúklings. Dánartíðni yfir 5 ára tímabil hjá sjúklingum með bráða blæðingu frá efri hluta meltingarvegar (39\%) er hærri en í viðmiðum (26\%) pegar leiðrétt er fyrir aldri, kyni og fylgisjúkdómum, hættuhlutfall 1,4 (95\% ÖB 1,1-1,9) [óbirt gögn] en pessi munur er ekki til staðar í samanburði einstaklinga með blæðingu frá neðri hluta og viðmiða, 70\% á móti 75\%. ${ }^{69}$ Af 118 sjúklingum á Íslandi með óútskýrða sýnilega blæðingu árið 2010, voru einungis 5\% sem blæddi aftur á rúmlega priggja ára eftirfylgdartímabili og enginn peirra greindist með illkynja mein á pessum tíma, ${ }^{70}$ sem bendir til pess að ekki sé pörf á mjög péttu eftirliti í pessum tiltekna sjúklingahópi.

\section{Niơurlag}

Blæðingar frá meltingarvegi eru algengt viðfangsefni á bráðasjúkrahúsum. Áhættu- og orsakapættir eru fjölpættir en með góðri sögutöku er í mörgum tilfellum hægt að fá góða hugmynd um upptök og orsök blæðingar. Nýlega hafa komið fram áhættulíkön sem geta reynst hjálpleg pegar ákvarða parf hvaða einstaklingar purfa bráđa innlögn á spítala og hverjir ekki. Fái sjúklingar rétta meðhöndlun með vökva- og blóðgjöf, auk frekari inngripa í sumum tilfellum, eru horfur góðar.

\section{Pakkir}

Við kunnum Hallgrími Guðjónssyni, meltingarlækni, miklar pakkir fyrir yfirlestur og vandaðar athugasemdir. 


\section{Heimildir}

1. Hreinsson JP, Kalaitzakis E, Gudmundsson S, Bjornsson ES. Upper gastrointestinal bleeding: incidence, etiology and outcomes in a population-based setting. Scand $J$ Gastroenterol 2013; 48: 439-47.

2. Hreinsson JP, Gumundsson S, Kalaitzakis E, Björnsson ES. Lower gastrointestinal bleeding: incidence, etiology, and outcomes in a population-based setting. Eur J Gastroenterol Hepatol 2013; 25: 37-43.

3. Loperfido S, Baldo V, Piovesana E, Bellina L, Rossi K, Groppo M, et al. Changing trends in acute upper-GI bleeding: a population-based study. Gastrointest Endosc 2009; 70: 212-24.

4. Paspatis GA, Konstantinidis K, Chalkiadakis I, Tribonias G, Chlouverakis G, Roussomoustakaki M. Changing trends in acute upper gastrointestinal bleeding in Crete, Greece: a population-based study. Eur J Gastroenterol Hepatol 2012; 24: 102-3.

5. Theocharis GJ, Thomopoulos KC, Sakellaropoulos G, Katsakoulis E, Nikolopoulou V. Changing trends in the epidemiology and clinical outcome of acute uppe gastrointestinal bleeding in a defined geographical area in Greece. J Clin Gastroenterol 2008; 42: 128-33.

6. Ahsberg K, Hoglund P, Kim WH, von Holstein CS. Impact of aspirin, NSAIDs, warfarin, corticosteroids and SSRI on the site and outcome of non-variceal upper and lowe gastrointestinal bleeding. Scand J Gastroenterol 2010; 45: 1404-15.

7. Lanas A, Garcia-Rodriguez LA, Polo-Tomas M, Ponce M, Alonso-Abreu I, Perez-Aisa MA, et al. Time trends and impact of upper and lower gastrointestinal bleeding and perforation in clinical practice. Am J Gastroenterol 2009; 104: 1633-41.

8. Longstreth GF. Epidemiology and outcome of patients hospitalized with acute lower gastrointestinal hemorrhage: a population-based study. Am J Gastroenterol 1997; 92: 419-24.

9. Salomon JA, Wang H, Freeman MK, Vos T, Flaxman AD Lopez AD, et al. Healthy life expectancy for 187 countries, 1990-2010: a systematic analysis for the Global Burden Disease Study 2010. Lancet 2012; 380: 2144-62.

10. Arroja B, Cremers I, Ramos R, Cardoso C, Rego AC, Caldeira A, et al. Acute lower gastrointestinal bleeding management in Portugal: a multicentric prospective 1-year survey. Eur J Gastroenterol Hepatol 2011; 23: 317 22.

11. Blatchford O, Davidson LA, Murray WR, Blatchford M, Pell J. Acute upper gastrointestinal haemorrhage in west of Scotland: case ascertainment study. BMJ 1997; 315: 5104.

12. Rockall TA, Logan RF, Devlin HB, Northfield TC. Incidence of and mortality from acute upper gastrointestinal haemorrhage in the United Kingdom. Steering Committee and members of the National Audit of Acute Uppe Gastrointestinal Haemorrhage. BMJ 1995; 311: 222-6.

13. Makela JT, Kiviniemi H, Laitinen S, Kairaluoma MI. Diagnosis and treatment of acute lower gastrointestinal bleeding. Scand J Gastroenterol 1993; 28: 1062-6.

14. Raju GS, Gerson L, Das A, Lewis B, American Gastroenterological A. American Gastroenterological Association (AGA) Institute technical review on obscure gastrointestinal bleeding. Gastroenterology 2007; 133: 1697-717

15. Ell C, May A. Mid-gastrointestinal bleeding: capsule endoscopy and push-and-pull enteroscopy give rise to a new medical term. Endoscopy 2006; 38: 73-5.

16. van Leerdam ME, Vreeburg EM, Rauws EA, Geraedts AA, Tijssen JG, Reitsma JB, et al. Acute upper GI bleeding: did anything change? Time trend analysis of incidence and outcome of acute upper GI bleeding between 1993/1994 and 2000. Am J Gastroenterol 2003; 98: 1494-9.

17. Olafsson G, Hreinsson J, Björnsson E. Incidence of diverticular bleeding: a population-based study. Scand J Gastroenterol 2019: 54: 205-9

18. Hreinsson JP, Palsdottir S, Bjornsson ES. The Association of Drugs With Severity and Specific Causes of Acut Lower Gastrointestinal Bleeding: A Prospective Study. J Clin Gastroenterol 2016; 50: 408-13.

19. Gayer C, Chino A, Lucas C, Tokioka S, Yamasaki T, Edelman DA, et al. Acute lower gastrointestinal bleeding in 1,112 patients admitted to an urban emergency medical center. Surgery 2009; 146: 600-6; discussion 6-7.

20. Carson JL, Strom BL, Soper KA, West SL, Morse ML. The association of nonsteroidal anti-inflammatory drugs with upper gastrointestinal tract bleeding. Arch Intern Med 1987; $147: 85-8$

21. Gabriel SE, Jaakkimainen L, Bombardier C. Risk for Serious Gastrointestinal Complications Related to Use of Nonsteroidal Antiinflammatory Drugs - a Metaanalysis. Ann Int Med 1991; 115: 787-96.

22. Hernandez-Diaz S, Rodriguez LAG. Association between nonsteroidal anti-inflammatory drugs and upper gastrointestinal tract bleeding/perforation - An overview of epidemiologic studies published in the 1990s. Arch Int Med 2000; 160: 2093-9.

23. Sostres C, Gargallo CJ, Arroyo MT, Lanas A. Adverse effects of non-steroidal anti-inflammatory drugs (NSAIDs, aspirin and coxibs) on upper gastrointestinal tract. Best Pract Res Clin Gastroenterol 2010; 24: 121-32.

24. Bjarnason I. Gastrointestinal safety of NSAIDs and overthe-counter analgesics. Int J Clin Pract 2013; 67: 37-42.

25. Flower RJ. The development of COX2 inhibitors. Nat Rev Drug Discov 2003; 2: 179-91.

26. Lanas A, Sekar MC, Hirschowitz BI. Objective Evidence of Aspirin Use in Both Ulcer and Nonulcer Upper and Lower Gastrointestinal-Bleeding. Gastroenterol 1992; 103: 862-9.

27. Langman MJS, Morgan L, Worrall A. Use of anti-inflammatory drugs by patients admitted with small or large bowel perforations and hemorrhage. BMJ (Clin Res Ed) $1985 ; 290: 347-9$

28. Holt S, Rigoglioso V, Sidhu M, Irshad M, Howden CW Mainero M. Nonsteroidal antiinflammatory drugs and lower gastrointestinal bleeding. Dig Dis Sci 1993; 38: 161923.

29. Wilcox CM, Alexander LN, Cotsonis GA, Clark WS Nonsteroidal antiinflammatory drugs are associated with both upper and lower gastrointestinal bleeding. Dig Dis Sci 1997; 42: 990-7.

30. Chang CH, Lin JW, Chen HC, Kuo CW, Shau WY, Lai MS, Non-steroidal anti-inflammatory drugs and risk of lower gastrointestinal adverse events: a nationwide study in Taiwan. Gut 2011; 60: 1372-8.

31. Yuan J, Yang M, Threapleton D, Oi X, Ye D, Mao C, et al. Systematic review with meta-analysis: the gastrointestinal benefits of COX-2 selective inhibitors with concomitant use of low-dose aspirin. Aliment Pharm Therap 2016; 44: 785-95.

32. Lanas A, García-Rodríguez L-A, Arroyo M-T, Gomollón F, Feu F, González-Pérez A, et al. Risk of upper gastrointestinal ulcer bleeding associated with selective cyclo-oxygenase- 2 inhibitors, traditional non-aspirin non-steroidal anti-inflammatory drugs, aspirin and combinations. Gut 2006; 55: 1731-8.

33. Loll PJ, Picot D, Garavito RM. The Structural Basis of Aspirin Activity Inferred from the Crystal-Structure of Inactivated Prostaglandin H-2 Synthase. Nat Struct Biol 1995; 2: 637-43

34. Hallas J, Dall M, Andries A, Andersen BS, Aalykke C, Hansen JM, et al. Use of single and combined antithrombotic therapy and risk of serious upper gastrointestinal bleeding: population based case-control study. BMJ 2006; 333: 726

35. Garcia Rodriguez LA, Lin KJ, Hernandez-Diaz S, Johansson S. Risk of upper gastrointestinal bleeding with low-dose acetylsalicylic acid alone and in combination with clopidogrel and other medications. Circulation 2011; 123: 1108-15.

36. Sorensen HT, Mellemkjaer L, Blot WJ, Nielsen GL, Steffensen FH, McLaughlin JK, et al. Risk of upper gastrointestinal bleeding associated with use of low-dose aspirin. Am J Gastroenterol 2000; 95: 2218-24.

37. Huang ES, Strate LL, Ho WW, Lee SS, Chan AT. A Prospective Study of Aspirin Use and the Risk of Gastrointestinal Bleeding in Men. PloS one 2010; 5: e15721.

38. Huang ES, Strate LL, Ho WW, Lee SS, Chan AT. LongTerm Use of Aspirin and the Risk of Gastrointestinal Bleeding. Am J Med 2011; 124: 426-33.

39. Hurlen M, Abdelnoor M, Smith P, Erikssen J, Arnesen H. Warfarin, aspirin, or both after myocardial infarction. N Engl J Med 2002; 347: 969-74.

40. Delaney JA, Opatrny L, Brophy JM, Suissa S. Drug-drug interactions between antithrombotic medications and the risk of gastrointestinal bleeding. Can Med Assoc J 2007; 177: $347-51$

41. Tran HA, Chunilal SD, Harper PL, Tran H, Wood EM, Gallus AS. An update of consensus guidelines for warfarin reversal. Med J Aust 2013; 198: 198-9.
42. Miller CS, Dorreen A, Martel M, Huynh T, Barkun AN. Risk of Gastrointestinal Bleeding in Patients Taking NonVitamin K Antagonist Oral Anticoagulants: A Systematic Review and Meta-analysis. Clin Gastroenterol H 2017; 15: 1674-83. e3.

43. Scridon A, Serban RC. Laboratory monitoring: a turning point in the use of new oral anticoagulants. Therap Drug Monitoring 2016; 38: 12-21.

44. Cuker A, Burnett A, Triller D, Crowther M, Ansell J, Van Cott EM, et al. Reversal of direct oral anticoagulants: Guidance from the Anticoagulation Forum. Am J Hematol 2019; 94: 697-709.

45. Bai Y, Shi X-B, Ma C-S, Lip GY. Meta-analysis of effectiveness and safety of oral anticoagulants in atrial fibrillation with focus on apixaban. Am J Cardiol 2017; 120: $1689-95$.

46. Marshall BJ, Warren JR. Unidentified curved bacilli in the stomach of patients with gastritis and peptic ulceration. Lancet 1984; 1: 1311-5.

47. Megraud F. Transmission of Helicobacter pylori: faecal-oral versus oral-oral route. Aliment Pharmacol Ther 1995. 9 Suppl 2: 85-91.

48. Asgeirsdottir G, Kjartansdottir I, Olafsdottir A, Hreinsson J, Hrafnkelsson $\mathrm{H}$, Johannsson E, et al. Helicobacter pylori infection in Icelandic children. Scand J Gastroenterol 2017; 52: 686-90.

49. Sung JJ, Chiu PW, Chan FK, Lau JY, Goh K-1, Ho LH, et al. Asia-Pacific working group consensus on non-variceal upper gastrointestinal bleeding: an update 2018. Gut 2018; 67: 1757-68.

50. Strate LL, Gralnek IM. ACG clinical guideline: management of patients with acute lower gastrointestinal bleeding. Am J Gastroenterol 2016; 111: 459.

51. Stanley AJ, Laine L, Dalton HR, Ngu JH, Schultz M, Abazi R, et al. Comparison of risk scoring systems for patients presenting with upper gastrointestinal bleeding: international multicentre prospective study. BMJ 2017; 356: 16432.

52. Hreinsson JP, Sigurdardottir R, Lund SH, Bjornsson ES. The SHA2PE score: a new score for lower gastrointestinal bleeding that predicts low-risk of hospital-based intervention. Scand J Gastroenterol 2018; 53: 1484-9.

53. Oakland K, Jairath V, Uberoi R, Guy R, Ayaru L, Mortensen $\mathrm{N}$, et al. Derivation and validation of a novel risk score for safe discharge after acute lower gastrointestinal bleeding: a modelling study. Lancet Gastroenterol Hepatol 2017; 2: 635-43.

54. Sung JJ, Barkun A, Kuipers EJ, Mössner J, Jensen DM, Stuart R, et al. Intravenous esomeprazole for prevention of recurrent peptic ulcer bleeding: a randomized trial. Ann Intern Med 2009; 150: 455-64.

55. Leontiadis GI, Sharma VK, Howden CW. Proton pump inhibitor therapy for peptic ulcer bleeding: Cochrane collaboration meta-analysis of randomized controlled trials. Mayo Clinic Proceedings 2007; 82: 286-96.

56. Barkun AN, Bardou M, Kuipers EJ, Sung J, Hunt RH, Martel M, et al. International consensus recommendations on the management of patients with nonvariceal upper gastrointestinal bleeding. Ann Intern Med 2010; 152: 101-

57. Gralnek IM, Dumonceau J-M, Kuipers EJ, Lanas A, Sanders DS, Kurien M, et al. Diagnosis and management of nonvariceal upper gastrointestinal hemorrhage: European Society of Gastrointestinal Endoscopy (ESGE) Guideline. Endoscopy 2015; 47: a1-46.

58. Rodriguez EA, Donath E, Waljee AK, Sussman DA. Value of Oral Proton Pump Inhibitors in Acute, Nonvariceal Upper Gastrointestinal Bleeding: A Network MetaAnalysis. J Clin Gastroenterol 2017; 51: 707-19.

59. Freston J, Pilmer B, Chiu YL, Wang Q, Stolle J, Griffin $\mathrm{J}$, et al. Evaluation of the pharmacokinetics and pharmacodynamics of intravenous lansoprazole. Aliment Pharm Therap 2004; 19: 1111-22.

60. Tripathi D, Stanley AJ, Hayes PC, Patch D, Millson C, Mehrzad $\mathrm{H}$, et al. UK guidelines on the management of variceal haemorrhage in cirrhotic patients. Gut 2015; 64: 1680-704.

61. Ioannou GN, Doust J, Rockey DC. Terlipressin for acute esophageal variceal hemorrhage. Cochrane Database Syst Rev 2003: CD002147. 
62. Chavez-Tapia N, Barrientos-Gutierrez T, Tellez-Avila F, Soares-Weiser K, Mendez-Sanchez N, Gluud C, et al. Meta-analysis: antibiotic prophylaxis for cirrhotic patients with upper gastrointestinal bleeding-an updated Cochrane review. Alim Pharmacol Therap 2011; 34: 50918.

63. Hreinsson $\mathrm{K}$, Guðmundsson S, Steingrímsdóttir $\mathrm{H}$, Birgisson G, Jóhannesson A. Klínískar leiðbeiningar um notkun blóðhluta á Landspítala. Landspítali, Reykavík 2012. landspitali.is/library/Sameiginlegar-skrar/ Gagnasafn/BRUNNURINN/Kliniskar-leidbeiningar/ Blodhlutar/klin_leid_notkun_blodhluta_sept_2012.pdf apríl 2019.

64. Jairath V, Kahan BC, Gray A, Dore CJ, Mora A, James MW, et al. Restrictive versus liberal blood transfusion for acute upper gastrointestinal bleeding (TRIGGER): a pragmatic, open-label, cluster randomised feasibility trial. Lancet 2015; 386: 137-44

65. Villanueva C, Colomo A, Bosch A, Concepcion M, Hernandez-Gea V, Aracil C, et al. Transfusion strategies for acute upper gastrointestinal bleeding. N Engl J Med 2013; 368: 11-21.

66. Sung JJ, Lau JY, Ching JY, Wu JC, Lee YT, Chiu PW, et al. Continuation of low-dose aspirin therapy in peptic ulcer bleeding: a randomized trial. Ann Intern Med 2010; 152: 1-9.

67. Oakland K, Chadwick G, East JE, Guy R, Humphries A, Jairath $V$, et al. Diagnosis and management of acute lower gastrointestinal bleeding: guidelines from the British Society of Gastroenterology. Gut 2019: gutinl-2018-317807.
68. Green BT, Rockey DC, Portwood G, Tarnasky PR, Guarisco S, Branch MS, et al. Urgent colonoscopy for evaluation and management of acute lower gastrointestinal hemorrhage: a randomized controlled trial. Am J Gastroenterol 2005; 100: 2395.

69. Hreinsson JP, Egisdottir S, Bjornsson ES. Acute lower gastrointestinal bleeding: A population-based five-year follow-up study. Un Eur Gastroenterol J 2019;2050640619863517.

70. Hreinsson JP, Bjarnason I, Bjornsson ES. The outcome and role of drugs in patients with unexplained gastrointestinal bleeding. Scand J Gastroenterol 2015; 50: 1482-9.

\title{
Gastrointestinal bleeding in Iceland and in broader terms - a review
}

\author{
Jóhann P. Hreinsson ${ }^{1}$ \\ Einar S. Björnsson ${ }^{2,3}$
}

Gastrointestinal bleeding is a common cause for presentation in the emergency room and hospitalization. The bleeding is usually categorized to upper or lower gastrointestinal bleeding. The purpose of this review article is to provide an overview of the incidence of gastrointestinal bleeding, etiology, risk factors, role of antithrombotics, evaluation of the severity of bleeding, therapy and outcome. Emphasis will be put on gastrointestinal bleeding within the Icelandic health care system but also in broader terms.

'Division of Medical Gastroenterology, Department of Internal Medicine, Sahlgrenska University Hospital, Gothenburg, Sweden, ${ }^{2}$ Faculty of Medicine, University of Iceland, Reykjavík, Iceland, 3Division of Gastroenterology and Hepatology, Department of Internal Medicine, The National University Hospital of Iceland, Reykjavík, Iceland.

Key words: Gastrointestinal haemorrhage, GI bleeding overview, Antithrombotic therapy, GIB risk evaluation.

Correspondence: Jóhann P. Hreinsson, hreinssonjp@gmail.com

\section{Leiðrétting}

Í greinina Hæðarveiki og tengdir sjúkdómar í nóvemberblaðinu (Læknablaðið 2019; 105: 499-507) vantaði pví miður eina töflu við birtingu og upplýsingar á mynd 3 voru ekki réttar. Beðist er velvirðingar á pessari handvömm, petta hefur verið leiðrétt á netinu og í nýjum pdf. 